Chapter Five

\title{
THE CRITIQUE OF THEODICY: FROM METAPHYSICS TO PRAXIS
}



$S_{\text {INCE the dawn of religious thought, theodicy has been a para- }}$ mount problem. The significance of this question is quite obvious: if we assume that God is good, and if a good God can do no evil, the existence of evil refutes the existence of God. Classic philosophical traditions have confronted this question through a series of explanations that deny evil its unique character, either by denying the reality of evil or by providing teleological or causal explanations for its existence. Causal explanations show that, even if evil exists, it is justified. God, then, does not operate arbitrarily but as a good and rational entity. The assumption of God's goodness also allows for a solution of the theodicy problem that rests on the infinite gap between human beings and God, which prevents them from understanding God's actions. Recognition of this epistemic gap enables human beings to go on believing in God's goodness, even if it cannot provide an acceptable explanation for the existence of evil. ${ }^{1}$

Beyond the differences between the various explanations, all assume that not only is the theodicy question legitimate but also that failing to solve it constitutes a refutation of God's existence 
and results in religious life losing its meaning. Contrary to this stance, a widespread approach in contemporary Jewish thought casts doubt on both the gravity of this question and on the classic approaches to its solution. From a crucial theological question, theodicy turns into a kind of litmus test of the believer's stance in the world. The shift from a theological concern to the individual's religious disposition reflects a wider trend in contemporary Jewish philosophy, focusing on religious life rather than on classic theological issues.

Two trends can be discerned in this philosophy - one is sharply critical of classic theodicy's basic assumptions, while the other formulates a social-existential critique of it. The first is represented by Yeshayahu Leibowitz and Eliezer Goldman and the other by Joseph B. Soloveitchik and David Hartman.

\section{The Critique of Classic Theodicy}

Goldman and Leibowitz negate the legitimacy of the theodicy question outright resting on two mutually complementary elements: the first is God's absolute transcendence, and the second is the neutrality of historical events. The assumption of God's transcendence in the work of both these thinkers is not only epistemological, confined to the claim that God is not amenable to human knowledge, but also ontological, claiming an infinite, unbridgeable gap between God and human beings. The latter, complementary claim, states that human history is religiously neutral. After discussing Leibowitz's formulation of these claims in previous chapters, this chapter will focus mainly on Goldman's articulation of these two assumptions.

Goldman engages in a critical dialogue with Leibowitz and draws a distinction between illusory and non-illusory faith, both 
of which contend with the fundamental problem of an imperfect human reality:

The consciousness of the religious person is generally sensitive to flaws in human reality. Even when the contemplation of human reality does not necessarily highlight these flaws, its contrast with the description of divine perfection must evoke reflections about its failings. These flaws - death, sin, dark inclinations, the flimsy foundations of human knowledge, the inevitable confusion between good and evil... appear to cast doubt on the possibility of any association between humanity and its Creator. ${ }^{2}$

Given these problems, argues Goldman, two opposite "typological" reactions are possible. One, the "redemptive religiosity that Leibowitz calls illusory religion," assumes that religion promises to amend the world, bringing release from reality's flaws and true closeness to God. Goldman then adds: "In its most developed forms, this religiosity aspires to liberation from the bonds of reality up to its elimination. Religion thus redeems human beings from the fundamental flaws of their reality." ${ }^{3}$

According to Goldman, illusory religiosity has two main manifestations - an eschatological view of reality and "the ontological perception of reason" (362). The eschatological view assumes several modes, "from magic to contemplation" (361), which must be addressed because Jewish literature includes several variations of what appears to be an eschatological perception such as, for instance, the widespread use of the term "redemption" in biblical literature. To reject this approach, Goldman argues that the biblical concept of redemption "does not relate to man's fundamental conditions of existence, but to specific historical conditions. This is redemption from political subjugation and at times from wicked government" (361-362). Goldman is aware that recourse 
to miracles involving supernatural elements is a widespread characteristic of Jewish literature. His response to them is: "Even the descriptions of miracles including an expectation of change in the natural order do not redeem man in the sense we are using this term here. Hence, eschatological visions do not prove that Judaism is a redemptive religion" (362). In other words, even if the natural order changes, the real character of human existence will not; according to Jewish sources, no "transformation of human reality, releasing it from its flaws," is to be expected (361).

Goldman's analysis, however, seems questionable. To claim that Jewish sources do not include transformational perceptions of human nature is an exaggeration. Goldman's critique of eschatological outlooks appears to rely on halakhic tradition on the one hand, and on an epistemological critique of the assumptions underlying the eschatological outlook on the other. The latter are my concern in this chapter.

Both Goldman's and Leibowitz's main claim is that God's ontological transcendence precludes claims about changes in human reality. This, according to Goldman, is the "non-illusory religion": "In non-illusory religion, the essence of the religious stance is the contrast between the Creator and the created reality, and the unbridgeable gap between the human and the divine. Human reality must be accepted as is, without any illusion of escape" (361).

According to the view both these thinkers share, real history is a neutral arena from a religious perspective. In Leibowitz's formulation:

The whole of natural reality is religiously irrelevant - "the world pursues its course"... God is not revealed in natural reality, and the claim of "God's hand" in a natural event bears traces of pantheism or polytheism... No meaning should be 
sought in history that, like nature, is meaningless... and no religious aura should be attached to the course of history. ${ }^{4}$

This neutrality is the antithesis of eschatological, illusory religion.

Another, different mechanism is also part of this type of religiosity: "the ontological perception of reason." Contrary to the previous approach, this one does not cope with the incongruity between reality's flaws and God's perfection by offering eschatological hope. Instead, it attempts to decode the rational character of human reality. Whereas eschatology rejects human reality, the ontological perception of reason reaffirms it through a rational explanation that mediates between reality and God. This perception dismisses the gap between the divine and the human and assumes that human beings, through their cognition, can understand the rationality of this ostensibly irrational reality. Through theodicy, for instance, human beings can understand that what appears to be evil is actually good or, at least, is a means for attaining the good.

Goldman's rejection of this trend fits his assumption about God's transcendence. But Goldman, as a critical thinker, is reluctant to rely on this perception to reject another view because such a move would lead him to a petitio principii fallacy. His rejection is based on his critique of human cognition: "The question of human wisdom is not religious but philosophical. Only in light of our philosophical perception of wisdom can we adopt a religious attitude toward it." 5

This link between religion and human cognition again points to Goldman's unique position. Though he shares Leibowitz's rejection of a special religious epistemology, he is not a partner to Leibowitz's thesis on compartmentalization. ${ }^{6}$ Goldman rejects the thesis that religion creates a separate, autonomous world. Instead, he holds that, after a critical analysis of human cognition, 
one can again determine a religious stance toward it. Goldman's argument is that an epistemological critique of the ontological view of reason could be the catalyst for rejecting the religious world. Furthermore:

Many who follow such an epistemology are driven by an antireligious motivation. For them, it is part of the ideology that ascribes importance only to human values and scientific cognition and refuses to acknowledge relevance or "meaning" in anything beyond this frame of reference, which human beings could sense they have transcended. (363)

This approach, however, is not the necessary conclusion of rejecting the ontological view of reason. Another option is that the rejection of ontological rationalism constitutes an amendment of religion and a removal of illusory elements from Judaism (363). The critique of reason, which is religiously neutral, is thus an efficient means for amending religion even if this had not been its goal. What, then, is the critique of ontological rationalism?

As is well known, the perception of reason as an ontological element of which human reason is part has long been questioned. Many epistemologies reject it, among them not only those known as positivistic or pragmatic but even some of those known as idealistic. According to this view, what is known as the rational structure of the world is merely the structure of its thinking tools, of language and of consciousness, as well as our experimental tools. We discover order in the world because of the selective way in which we arrange it in our understanding. (362-363)

These general statements, formulated in Goldman's programmatic article "On Non-Illusory Faith" published in 1960, appear in far greater detail in an obscure critique he had published five years 
previously entitled "Divine Good and Human Good."7 This is a particularly interesting piece because it focuses precisely on the problem of theodicy and, in fascinating ways, applies the general insights presented above to a set of claims leading to a negation of classical theodicy.

Goldman's first critique relates to what might be called "lack of moral symmetry." This argument assumes: "If God planted in us specific moral feelings, the contents of these feelings apply to God as well... [According to this claim], a belief in Providence is ultimately identical to a belief that the world behaves as it should have behaved according to his [the believer in symmetry] view" (15).

But this symmetry, based on the assumption that man is created in God's image, is not logically substantiated and reflects what Goldman calls a type of "primary experiences" (15). These experiences reflect our basic perceptions about existence. The fundamental experience of the supporters of moral symmetry is manifest in the immanent perception of God: human beings and God belong to the same moral community and this is why we can judge God's goodness and providence. Yet, argues Goldman:

By contrast, another religious consciousness is built upon a sense of the absolute asymmetry of creation in God's image. God's seal is imprinted upon us, but even the mere thought of attempting to imprint our seal upon God seems a type of idolatry. If our day-to-day life as his worshippers is determined by the rule "Dismiss your will before His [Avot 2: 4]," I find it hard to understand a problematic resting on the assumption that God must direct his actions according to our will. (15)

By pointing at different primary experiences, Goldman shows that the theodicean discourse cannot be conducted as a rational discourse involving decision-making rules; these experiences are 
not "a subject of theoretical discourse" (15). Endorsing or negating the theodicy discourse, then, is no more than a confession about, or an explication of, primary religious experiences. Goldman thereby dramatically minimizes the role and the meaning of theodicy in religious life, no longer viewing it as its constitutive basis and turning it instead into a personal, random matter. Indeed, Goldman goes even a step further. He seeks to re-examine to what extent supporters of the theodicean discourse reflect a logical discourse that is not self-contradictory:

At this point, there is room for showing to what extent we succeed in consistently clinging to our primary experiences and to what extent they lead us to contradictions. Furthermore, it sometimes appears to us that our primary experiences can be expressed in a statement that seems a logical conclusion of other statements we have accepted. Here too, there is room for considering whether these seemingly logical contexts do indeed exist. (15)

This move is even more radical than the previous one and, through it, Goldman points out not only the contingent and episodic nature of the theodicean discourse but also several of its fallacies.

The starting assumption of the theodicean discourse is God's characterization as a good God. Since God is perceived as morally good, an evil reality is perceived as a contradiction to God's existence. In this discourse, the good is apprehended as a "common attribute" of God and humanity, and this partnership enables the theodicean discourse. Goldman, however, argues that the good is not necessarily a common feature:

When we speak of a red house, a red book, red wine, and so forth, the term "red" appears as a common attribute of various 
objects... By contrast, when we speak of a good book, a good cobbler, or a good teacher, the attribute leading us to claim that a particular one is good is different in each case. The term "good" is evaluative. In each of the contexts we use it, we assume a criterion that we generally use in that particular context and serves us to evaluate objects or actions positively or negatively. The use of the term "good" in two different contexts does not prove that we are using the same criterion in both cases. (15)

This analysis attests that the shared component of these modes of use in the term "good" is merely formal and therefore entirely empty: "good" is an expression of judgment and evaluation but not necessarily moral judgment and evaluation. ${ }^{8}$ What, then, is the meaning of the term good in regard to God? Is it a moral evaluation? Goldman answers: "In the context of metaphysical methods used by classic theologians, the term [good] was intended as some kind of unique metaphysical perfection in God. Classic theology always stresses the metaphorical character of the term 'good' in reference to God" (15). Indeed, the use of the concept good in the sense pointed out by Goldman is prominent already in Platonic tradition: good is self-containment and independence from external elements. Plato formulates this as follows: "The good differs from everything else in a certain respect... A creature that possesses it permanently, completely, and absolutely, has never any need of anything else; its satisfaction is perfect." 9

This analysis, however, does not entirely undermine the theodicean discourse because religious traditions in general, and Jewish ones in particular, abound with moral value statements about God. Even if Greek tradition and classic theology used "good" concerning God as denoting perfection and wholeness, we could still claim that religious traditions use "good" concerning God in its common moral denotation. To reject this option, Goldman engages in a series of moves. First, if we do indeed 
adhere to the language of Jewish tradition, assigning God only the quality of moral goodness would not fit the tradition itself:

This is a matter of choosing the convenient verses. Other descriptions could be cited - "jealous and vengeful" "full of wrath" "puts no trust in his servants" - showing an entirely different attitude of the Creator to his creatures. A suitable choice of biblical verses could even support a description of a cruel despot that Christians and liberal critics sometimes wish to present as the prophets' description of God. ${ }^{10}$

Second, according to Goldman, Jewish tradition rejected "simplistic" theodicy as a response to the problem of "divine justice." Goldman illustrates this view with several examples, such as, for instance: "Isaiah ascribes to the Creator the proclamation 'I make peace and create evil,' which was imperative to eradicate idolatry and instill faith in the unity and uniqueness of God" (16). Relating to his general stance, Goldman then proceeds to claim: "I think this conclusion is unavoidable if we wish to preserve faith in God's uniqueness and, at the same time, arrive at a realistic evaluation of man's fate as a natural creature" (16).

Nevertheless, Goldman does understand that gross displays of evil could threaten religious faith and that the Holocaust, for instance, could lead to the negation of God's existence. Goldman's answer is that this inference from the Holocaust "is one-sided and subjective." Someone with a different "temperament" may not conclude from the Holocaust that "God is dead," but something entirely different:

He might be so enthused by the miracle of the establishment of the State of Israel that the tragedy of European Jewry might sink in his eyes to a third or fourth level, by contrast with the 
great salvation. Such a person would be amazed of how one fails to see the hand of God and his great rescue, so to whose temperament should the Creator adapt his qualities? (16)

These considerations void the theodicean discourse from meaning and portray it as merely an individual's confession about his world, his expectations, his insights, and his values. The fit between a "religious criterion" and the "criterion of 'a man of the world'" (16) is hard to substantiate.

Goldman knows that religious tradition includes statements that seem to contradict his position, and he contends with them:

How, then, should we understand the end of Genesis 18 and Abraham's claim, "Shall not the judge of all the earth do right?" It seems nothing could be added to Maimonides' explanation of the Thirteen Principles. The attempt to understand God's attributes from his actions could even lead to contradictory results and meanings. He appears merciful and gracious and also vengeful and full of wrath. When the Torah describes his qualities, it does so in order to teach us what are the qualities we must see as divine in order to adhere to them. For us, this is also the meaning of the dialogue between Abraham and his God about Sodom. (16)

This interpretation of the biblical text is highly questionable. Goldman is indeed careful in his formulations, since he writes: "For us, this is also the meaning of the dialogue..." In other words, textual hermeneutics does not disclose the meaning of the text but its significance for us.

Through this view, Goldman hints at a more fundamental stance concerning the meaning of the canonical text, which he developed in several of his writings. In his programmatic article, "Scientific Statements and Religious Statements: Several Funda- 
mental Differences," Goldman draws a distinction between religious and scientific statements. He points out, for instance, that affirming a scientific statement means affirming both the linguistic phrase and its contents. Affirming a religious statement, however, means affirming the statement but not necessarily the contents it expresses, ${ }^{11}$ which may no longer be considered valid in light of cultural, historical, and personal changes. A claim that believers might affirm in certain cultural circumstances, could become unacceptable and even false in others. Advocates of the religious statement will then have to propose another interpretation.

Goldman reiterates this view of text in a general hermeneutical context, not necessarily a religious one:

We are attentive to a text when seeking in it its message to us rather than viewing it merely as an object of philologicalhistorical research. The text expresses a religious idea through concepts and metaphors germane to the culture and the environment where it was written. This message was transmitted in the context of the day-to-day life of its original recipients. An attentive interpretation is an attempt to decode the message in the concepts of our own lebenswelt. ${ }^{12}$

This view of the text points to Goldman's closeness to Rudolf Bultmann. Like Bultmann, Goldman recognizes the importance of demythologizing the text. Contrary to Bultmann, however, who proposes a hermeneutics where myth functions as a window that serves to expose the divine message or kerygma, Goldman views the hermeneutical process as the application of the text to the actual world. Goldman thereby suggests, as noted, an approach that balances the concrete and the religious contexts of human life. This distance between Goldman and Bultmann is also the distance between Goldman and Leibowitz, since Leibowitz interprets 
Scripture statically, resting on his assumptions of correct and incorrect from the perspective of Judaism. ${ }^{13}$

Goldman's approach to theodicy, then, reflects a combination of analytical criticism and religious considerations, an attempt to offer an alternative reading of the biblical text, which suggests a classical theodicy, without contradicting critical assumptions. The very option of an alternative reading suffices to dismiss the use of the biblical text to support or reject the theodicy discourse.

Both Goldman and Leibowitz offer an alternative reading of classical sources and challenge traditional views, and both must therefore contend with the question of whether Jewish tradition fosters this alternative reading. Both claim it indeed does and, moreover, both claim that the rejection of theodicy represents a higher religious stage than its acceptance. Following is Goldman's formulation:

One of the most important aims of religious education must be to raise popular religious consciousness to the level endorsed by deeper thinkers. This is not impossible. To us, the idea of repentance seems obvious, part of every religious Jew's fundamental assumptions. But what efforts did the prophets invest until the people came to this understanding! When Isaiah says that God will have mercy upon the wicked who forsakes His way, he is forced to add: "For my thoughts are not your thoughts." Ezekiel engages in the same debate: "Yet you say, The way of the Lord is unfair... Is my way unfair? Surely your ways are unfair!" Even among the prophets, some did not accept the notion of "repents of evil."14

According to Goldman, raising religious consciousness is tantamount to repentance: it is the amendment of religious life itself. Goldman, therefore, seeks in canonical religious sources the demand to change the original disposition, and renouncing the 
theodicean discourse is a change of this kind. Leibowitz's formulations on this count are even sharper. In his view, the theodicy problem is the believer's constant test. Passing this test means negating theodicy, since affirming theodicy means putting God to the human test. Leibowitz views Job as the paradigm of the believer who gradually changes his religious disposition because he understands God's absolute otherness and the gap that separates him from God. Leibowitz returns to this comparison between the sacrifice of Isaac and the Book of Job in several of his writings. ${ }^{15}$ Despite this comparison, however, he points to one important difference between Abraham and Job that is relevant to our present discussion. Contrary to Abraham, Job undergoes a transformation process that turns him into a believer: "And if Job was a parable, what is the moral? The moral is the return to the sacrifice of Isaac and to faith for its own sake. Except that, in Job, faith for its own sake is a conclusion reached after a huge struggle, while Abraham reached a decision to believe in God because of his sheer divinity without any discussion, debate, or hesitation."16

What is the nature of Job's struggle? Leibowitz leads us through its various the stages and points to its significance. Job contends with the suffering and the pain that afflicts him:

The argument rises to a level which becomes both loftier and more profound...It begins with Job's cry of protest against the iniquity in the governance of the world by its Creator, and his urgent demand for justice. Gradually, a new note is insinuated, which becomes more and more explicit as the argument proceeds. Job's suffering is no longer the focus of his protest; rather it is his inability to comprehend the meaning of his suffering... Job demands that God reveal to him why the world is as it is. The inscrutability of the creation, and of human fate in general and Job's in particular, has become a source of anguish deeper than the torment of the sense of iniquity. ${ }^{17}$ 
Job's friends suggest theodicy as a solution to his problem: "The three friends... deal with theodicy, that is, with the attempt to justify God, saying to him, you are forbidden to cast doubt on the fairness of divine judgment. Maybe you were not as righteous as you thought... and maybe you do not understand divine justice, the wisdom embodied in the way God conducts the world."18

Job rejects their view, not because he understands that theodicy is not a legitimate position but because it fails to answer his urgent questions. ${ }^{19}$ At this stage, Job and his friends agree that theodicy is a legitimate assumption. Only God's answer out of the whirlwind results in Job's awaited religious transformation. He had so far held that faith means assuming that God works for human beings and that, therefore, their circumstances must be related to God's direct action. Now, Job understands that God does not work for human beings, and "that he must decide whether to commit himself to faith in God and to His service in the world as it is, to believe in Him and to serve Him not for his (Job's) benefit, but because of His divinity." 20 Job now realizes what Abraham had realized at the outset: theodicy is not a legitimate assumption, because it erodes the foundations of faith.

When Leibowitz discuses the interpretation that denies theodicy in Job's story, he generally appears to be insensitive to the hermeneutical problematic. The denial of theodicy is, as it were, the only meaning of Job's story. In one place, however, he does show awareness of this question and formulates it in terms of hermeneutical circularity. Leibowitz juxtaposes Karl Barth's interpretation, which resembles his own, to that of Iris Murdoch, which states we must do the good for its own sake and not for any ulterior end, an interpretation Leibowitz describes as atheistic. Facing these contradictory views, Leibowitz writes: "This fact confirms the rule that interpretation does not follow the text; instead, the meaning of the text follows its interpreter." 21 
Leibowitz is again revealed as close to Bultmann, who also assumes that the approach to the biblical text is guided by religious presuppositions. ${ }^{22}$ Bultmann, though, assumes that textual interpretation is existential and the believer's individual and historical meaning is therefore significant. By contrast, Leibowitz perceives the believer in ahistorical and a-concrete terms. The believer is all believers, and Job's answer is therefore the answer of all believers: theodicy is an illegitimate element in the world.

Based on this assumption, Leibowitz returns repeatedly to the Sodom story. Goldman approaches this text aware of his hermeneutical tools, that is, of the interpreter's disposition as conferring meaning upon Abraham's story in Sodom. By contrast, Leibowitz tries to read events differently: "As the advocate of Sodom's defendants, Abraham adduces claims of justice, fairness, and compassion, which are human categories about which he 'kindly' concedes to argue with God. But when his faith is put to the test — he remains silent." 23

Beyond these differences, however, both thinkers agree that theodicy is a problem of the faithful, not of faith. Indeed, it is the faithful's supreme test: will they believe in God as God, whose role is to regulate human life. "Genuine" believers know that evil and suffering are not a religious problem but part of the natural reality. Even if they find it hard to reach this insight, this is indeed the concern of faith and this is the challenge it poses to human beings. Changing the believer's dispositions is thus an expression of actual faith.

\section{The Social-Existentialist Critique}

Joseph B. Soloveitchik devoted two essays to the theodicy question: "Kol Dodi Dofek," 24 and a later one, "A Halakhic Approach to Suffering." 25 In "Kol Dodi Dofek," Soloveitchik argues that evil 
and suffering can be discussed at two levels of existence: the "existence of fate" and the "existence of destiny." Soloveitchik describes a fate existence through a terminology drawing on existentialist tradition as one in which individuals perceive themselves as objects: "His being is empty, lacking any inwardness, any independence, any selfhood." 26 In a destiny existence, people will perceive themselves as dynamic, influential creatures:

It is an active mode of existence, one wherein man confronts the environment into which he was thrown, possessed of an understanding of his uniqueness, of his special worth, of his freedom, and of his ability to struggle with his external circumstances without forfeiting either his independence or his selfhood... Man is born like an object, dies like an object, but possesses the ability to live like a subject, like a creator, an innovator, who can impress his own individual seal upon his life and can extricate himself from a mechanical type of existence and enter into a creative, active mode of being. (54)

Soloveitchik argues that the question about the existence of evil cannot be detached from the individual's mode of conscious existence: consciousness will shape a person's attitude towards suffering and evil. People who perceive their existence in terms of fate will contend differently with this question than those who perceive their existence in terms of destiny. One who perceives existence in terms of fate contends with the problem of evil in two stages. The first stage is marked by confusion: "Man the object, bound in the chains of an existence of compulsion, stands perplexed and confused before that great mystery suffering... his being, shattered and torn, contradicts itself and negates its own value and worth." (52)

After the deep psychological upheaval, the sufferer strives to find a rational explanation to suffering and evil, to return 
the shattered psychological harmony. The yearning for a rational explanation engenders what Soloveitchik terms the "metaphysics of evil" (53), which enables the person to reach an accommodation with evil through "the denial of the existence of evil in the world" (53).

The link that Soloveitchik traces between the conscious disposition and the way of contending with suffering and evil is particularly illuminating. People who perceive themselves as objects thrown into existence cannot strive for change in existence itself, since the object is a final given. Their only course, then, is metaphysics, which does not demand action and does not impose responsibility because it explains what already is. This analysis is thus a conscious critique of the history of our contest with the problem of evil. According to this critique, posing the question in a classic metaphysical context blurs the character of human existence. In existentialist terms, the traditional discussion of theodicy is not an authentic human stand.

But Soloveitchik's critique is not confined to the conscious disposition. In his view, the classic approach to evil is based on an ethical-social mistake: "the denial of the existence of evil." Prima facie, this claim is exaggerated, since purposeful or causal explanations do not question the very existence of evil but place it within a broader conceptual framework. Only neo-Platonic metaphysical theories denied evil's very existence. This critique requires a clarification of Soloveitchik's argument. In his view, every explanation of evil implies a denial of the negative, destructive dimension of evil, since the explanation that makes evil understandable incorporates it into the rational conceptual framework of the divine good. Soloveitchik therefore argues that the fundamental features of evil as negation and destruction are denied in the metaphysical explanation. Accepting evil means accepting it as a non-reductive 
datum exposed in reality. This critique originates in a realistic orientation toward reality: "Judaism, with its realistic approach to man and his place in the world, understood that evil cannot be blurred or camouflaged... Evil is an undeniable fact. There is evil, there is suffering, there are hellish torments in this world... It is impossible to overcome the hideousness of evil through philosophico-speculative thought" (53).

Contrary to this approach to the problem of evil, Soloveitchik presents the concept of destiny. As opposed to the "man of fate," whose own self-perception is as a finished object, the "man of destiny" diverts the question away from metaphysics. A consciousness of destiny enables one to accept evil as is and to cope with it:

In the realm of destiny man recognizes the world as it is and does not wish to use harmonistic formulas in order to gloss over and conceal evil. The man of destiny is highly realistic and does not flinch from confronting evil face to face. His approach is an ethico-halakhic one, devoid of the slightest speculative-metaphysical coloration... In this dimension the center of gravity shifts from the causal and teleological aspect of evil...to its practical aspect... We ask neither about the cause of evil nor about its purpose, but rather about how it might be mended and elevated. How shall a person act in a time of trouble? What ought a man to do so that he not perish in his afflictions? (55-56)

From this perspective, the question of theodicy ceases to be legitimate and the ethical question arises instead: what should a person do given that evil actually exists? Whereas the answer to the former question is metaphysical theory, the answer to the latter one is action. Failure to measure up to the challenge 
posed by evil and the return to metaphysics imply the return to a non-authentic consciousness. Diverting the problem of evil from metaphysics to ethics reflects a subjective shift typical of contemporary Jewish thought. Through this shift, not God but individuals and the concrete reality within which they live become the bearers of religious experience and consciousness. ${ }^{27}$

This change in Soloveitchik's thought originates in two sources: Hermann Cohen's legacy and existentialist tradition. Cohen vehemently rejects recourse to metaphysics as a way of contending with suffering:

The metaphysics of suffering, which considers suffering as the fate of mankind, or even more ambiguously, as the fate of all living creatures, does not belong to an earnest religion: its earnestness has nothing to do with the play of poetry and art. Suffering only reaches ethical precision as social suffering... Only the religion of reason is moral religion, and only moral religion is truthful and true religion. ${ }^{28}$

Cohen's discussion of suffering highlights the social dimension of suffering as related to reciprocity in human relations. For Cohen, true religiosity contends with this social reality and not with the metaphysics of suffering. Soloveitchik, who dealt at length with Cohen's philosophy and was influenced by it, ${ }^{29}$ took from him the shift from metaphysics to practice and translated it into existentialist terminology. The categories of "fate" and "destiny" are a translation of the conventional existentialist analysis about authentic and unauthentic ways of life. Soloveitchik does not eschew Heideggerian terminology, which expresses the relationship between the two ways of life. Though thrown into existence, we are not denied our freedom. ${ }^{30}$ In Heidegger's term, the person is a "thrown possibility." When faced with 
suffering, confidence in our existence collapses. In existentialist terms, this is the experience of anxiety. Suffering shatters the harmony of human existence and forces us to face its anxiety, and the reaction should not be a denial of reality but a return to contend with it. Finally, contrary to Hermann Cohen, Soloveitchik does not formulate the problem of suffering as a social issue pivoted on interpersonal relations but as an oppressing personal question: "What ought a man to do so that he not perish in his afflictions?" 31

For Leibowitz, the meaning of suffering is a stage in the education toward faith but not part of faith itself, which overrides the meaning of suffering. Soloveitchik turns the tide: the meaning of suffering becomes the heart of the drama in religious life. He agrees with Leibowitz's rejection of metaphysics, but he does not agree with the rejection of the question; rather, this question will become the catalyst of the shift from metaphysics to praxis.

On closer scrutiny, it appears that Soloveitchik does not exhaust this shift. He chooses the practical shift as a default option - given the human inability to understand suffering, all that is left is to contend with it:

Only if man could grasp the world as a whole would he be able to gain a perspective on the essential nature of evil. However, as long as man's apprehension is limited and distorted, as long as he perceives only isolated fragments of the cosmic drama and the mighty epic of history, he remains unable to penetrate into the secret lair of suffering and evil...We, alas, view the world from its reverse side. We are, therefore, unable to grasp the all-encompassing framework of being. And it is only within that framework that it is possible to discern the divine plan, the essential nature of the divine actions. ${ }^{32}$ 
From this perspective, the shift from metaphysics to praxis reflects the limitations of human cognition rather than the acceptance of metaphysics' fundamental irrelevance. David Hartman formulates this critique as follows:

\begin{abstract}
Although Maimonides and Soloveitchik evidently gave up hope of making sense of God's justice, their explanation of human history still operates with this model. While Soloveitchik does not suppose that we shall ever achieve a full rational comprehension of God's actions in history, he does believe that, in principle, were we able to look at the world from God's vantage point, we would understand how all of human suffering is compatible with the belief in God as a loving Creator and just Lord of History ... believing in principle that events in history are the carriers of God's will, Soloveitchik looks forward to the eschatological moment of unity between nature and history, when the God of Creation will be manifestly mediated in His full loving justice in historical reality. In the meantime, however, the manner in which His justice operates is partly or largely inscrutable. ${ }^{33}$
\end{abstract}

This critique, which emphasizes the fact that the shift to practice does not entirely replace metaphysics, returns in Soloveitchik's attempt to answer the question he had posed, "What ought a man to do so that he not perish in his afflictions?" We would expect a practical answer to this question, pointing to the person's obligation to act in the world, yet his answer is:

The halakhic answer to this question is very simple. Afflictions come to elevate a person, to purify and sanctify his spirit, to cleanse and purge it of the dross of superficiality and vulgarity, to refine his soul and to broaden his horizons. In a word, the function of suffering is to mend that which is flawed in 
an individual's personality. The Halakhah teaches us that the sufferer commits a grave sin if he allows his troubles to go to waste and remain without meaning or purpose. Suffering occurs in the world in order to contribute something to man, in order that atonement be made for him... From out of its midst the sufferer must arise ennobled and refined, clean and pure. $^{34}$

Soloveitchik offers a teleological answer to this practical question. In this world, suffering has a purpose. Indeed, this purpose is not part of the purpose of universal or Jewish history but part of a series of conditions through which individuals amend and refine their being. The difference between this response and the traditional teleological response ultimately rests in the identification of a specific purpose for the existence of evil.

"Kol Dodi Dofek" shows Soloveitchik oscillating between metaphysical and practical language. The metaphysical language features in the text cited above and in the essay's general plan, intended to point out that Jewish history has a purpose. Contrary to traditional teleological approaches claiming that history realizes a given purpose, Soloveitchik offers a more complex version whereby God provides opportunities, to which human responses are expected. These opportunities are hints, as it were, of God's desirable goals. Interpreting and applying these hints is incumbent on human beings. In this sense, this approach assumes that the teleological movement of history is contingent on humanity. History, then, is a synergistic event unfolding as a partnership between God and the divine ends on the one hand and the human ability to respond to God's hints on the other. Suffering plays a significant role in God's hints, as an opportunity through which God suggests a new possibility. In the context of this approach, argues Soloveitchik, the Holocaust is a kind of occurrence that produced the State of Israel (69). 
Contrary to this metaphysical language, the text includes many expressions reflecting the adoption of a practical language. This is prominent in Soloveitchik's analysis of God's response to Job's suffering. Soloveitchik holds that Job's suffering is a test that will show whether he is still immersed in his egoism or will turn his gaze to the other and share in his suffering. Job, argues Soloveitchik, passed the test:

In a moment he discovered its plural form, he descried the attribute of hesed which sweeps the individual from the private to the public domain. He began to live the life of the community, to feel its griefs, to mourn over its calamities, and to rejoice in its happiness. The afflictions of Job found their true rectification when he extricated himself from his fenced-in confines, and the divine wrath abated: "And the Lord turned the captivity of Job, when he prayed for his friends" (Job 42: 10). ${ }^{35}$

This is a particularly prominent illustration of this trend because it inadvertently combines metaphysical and practical language. God's initiative - a test that Job passes - has a purpose, but this purpose is translated into the practical-interpersonal field.

This opaqueness gradually disappears in Soloveitchik's second essay, where he again contends with the question of suffering and evil. In "Kol Dodi Dofek," as noted, Soloveitchik assumes that "Judaism, with its realistic approach to man and his place in the world, understood that evil cannot be blurred or camouflaged" (53). Now, Soloveitchik seeks to draw a distinction between two different contexts for approaching suffering and evil: "topical Halakhah" and "thematic Halakhah." Topical Halakhah focuses on concrete reality. It does not offer a conceptual framework for a cognitive interpretation of reality, but a system of positive and formalistic attitudes for approaching reality in order to shape it: 
"The Halakhah does not venture outside of the human world, and the human world is a very small world. Whatever is relevant to man, to his interests, to his self-fulfillment and his self-realization is relevant and pertinent to the Halakhah. Whatever is irrelevant to man is irrelevant to the topical Halakhah." 36 Topical Halakhah is not interested in understanding the human creature in metaphysical terms, as an idea, but rather as an individual entity: “The Halakhah insists that nothing, not the idea nor the collective, should supplant the single transient and frail individual" (94).

Contrary to topical Halakhah, the concern of thematic Halakhah is the general, conceptual value system. This conceptual framework, which Soloveitchik leaves somewhat vague, can be understood through its contrast with topical Halakhah. Whereas topical Halakhah focuses on concrete existence and relates to it through a normative system of duties, thematic Halakhah creates a cohesive conceptual system of immanent meaning. This system exceeds the concrete and encompasses totality, "thematic Halakhah extends into infinity and eternity" (95). This difference between the two models comes to the fore in the attitude to suffering. According to Soloveitchik, thematic Halakhah enables and affirms theodicy: "Within the thematic Halakhah, we find a theodicy or, to be more precise, a metaphysic of suffering. Judaism, at the level of axiology or at the level of transcendental reference, did develop a metaphysic of evil, or, I would rather say, of suffering, of the passional experience" (95).

Soloveitchik argues that theodicy developed by drawing a distinction between suffering and evil. Suffering is perceived as a subjective experience, a kind of feeling, whereas evil describes an objective reality (95). This distinction enables to separate human suffering from concrete reality. We tend to ascribe suffering and pain to the objective existence of evil. Thematic Halakhah does not deny suffering, but claims that its source is not 
any objective evil: "This sharp distinction between evil and pathos opened up to the thematic Halakhah new vistas which explained suffering. It did so by denying the reality of evil in a twofold way, by introducing transcendentalism and universalism" (96).

Soloveitchik claims that evil is removed in two moves: the first, which he called the transcendental principle, is based on the expansion of ontological consciousness. If reality begins and ends with the concrete experience, the presence of evil undermines order and justice. But "evil vanishes as soon as the threshold of man's ontological consciousness is raised from the order of the sensible, phenomenal, and transient to a higher order of the absolute and eternal" (94). Soloveitchik illustrates this approach through several sources. Thus, for instance, he quotes the Talmud: "Thus the Holy One brings suffering upon the righteous in the world in order that they may inherit the future world... (Kiddushin $40 \mathrm{~b})$ " (97). By including the world to come within the concept of reality, evil is removed altogether (97).

Another source that Soloveitchik quotes is the Guide of the Perplexed III: 51, where Maimonides contends with the most dreadful of all evils - death — by idealizing old age as a reality that, together with a decaying body, brings with it a strengthened consciousness: "His joy is that knowledge grows greater, and his love for the object of his knowledge more intense, and it is in this great delight that the soul separates from the body" (98). Thematic Halakhah, then, neutralizes the terror of death by glorifying the rational element as the basis for the process of the soul's separation from the body. Since reality is not identical to sensorial bodily reality but to the rational reality that we approach as we approach death, its evil is removed.

The second principle in disposing of evil is the universalistic principle: "Thematic Halakhah maintains the universal doctrine of suffering that evil as a universal entity does not exist, 
that it is nothing but a chimera, just a figment of our fantasy. Suffering and misery are due to the accidental and contingent character of our existence, which is confined to a narrow segment of being" (98).

Indeed, not only does suffering reflect human contingency but "sufferings of the individual are ministerial to a higher good within a universal order... Evil is not an essential part of being if the latter is placed in the perspective of totality" (98).

In "Kol Dodi Dofek," Soloveitchik rejects these approaches by invoking halakhic realism. In "Approach to Suffering," he withdraws from this position because thematic Halakhah, which is part of Judaism, contends with suffering and evil by endorsing a metaphysical approach, to which theodicy provides the main access. Soloveitchik rejects this view through an argument combining existentialist and modernist outlooks, and claims that thematic Halakhah cannot console human suffering:

Can such a metaphysic bring solace and comfort to modern man who finds himself in crisis, facing the monstrosity of evil, and to whom existence and absurdity appear to be bound up inextricably together? Is there in the transcendental and universal message a potential of remedial energy? ... I can state with all candor that I personally have not been successful in my attempts to spell out this metaphysic in terms meaningful to the distraught individual who floats aimlessly in all-encompassing blackness... I tried but failed, I think, miserably, like the friends of Job. (99-100)

This text represents the radical turnabout in Soloveitchik's position: the criterion for evaluating the metaphysical theory is not the measure of its rationality or sophistication, but its ability to respond to true human needs. Its acceptance is contingent on its therapeutic powers, its "remedial energy." 
Soloveitchik's use of this criterion, however, is problematic. This criterion allows him to claim that thematic Halakhah could provide an answer, at least in principle. The preliminary condition for this is "indomitable faith and a passionate transcendental experience." Thematic Halakhah, then, has lost its comforting power only within the confines of modern life, where people are detached and alienated. This approach not only minimizes but entirely cancels out the religious meaning of the alternative approach to suffering and evil. On the other hand, Soloveitchik identifies thematic Halakhah (in this text as well as in "Kol Dodi Dofek") with Job's friends, who offer theodicy as the response to Job's suffering. The problematic of thematic Halakhah, then, is not contingent on modern reality, and reflects the gap between Halakhah and the angst of concrete existence. This trend fits in with the fact that contending with evil in the context of topical Halakhah does provide an answer to distress. Since topical Halakhah could not possibly be viewed as modern, the human distress to which this Halakhah is responding is not an expression of detachment and alienation from religious tradition but the basic human stance vis-à-vis existence. This ambivalence vis-àvis modernity is indeed a permanent component of Soloveitchik's thought.

Contrary to thematic Halakhah, the attitude of topical Halakhah to evil and suffering is entirely different. The realism of "Kol Dodi Dofek," which was a typical characteristic of Judaism, is now confined to topical Halakhah: "Realism and individualism, ineradicably ingrained in the very essence of the topical Halakhah, prevented it from casting off the burden of the awareness of evil" (100).

Topical Halakhah sees concrete reality in all its manifestations as the ultimate datum, which cannot be explained through a metaphysical theory: 
The topical Halakhah lacked neither the candor nor the courage to admit publicly that evil does exist, and it pleaded ignorance as to its justification and necessity. The topical Halakhah is an open-eyed, tough observer of things and events and, instead of indulging in a speculative metaphysic, acknowledged boldly both the reality of evil and its irrationality, its absurdity. (100)

The assumption that evil is absurd eliminates the option of contending with it through the "metaphysic of suffering" (102). Instead, topical Halakhah develops an "ethic of suffering" (102). This ethic is not meant to confer ontological meaning on suffering but to develop a human approach toward it. An ethic, contrary to a metaphysic, requires that we deliver ourselves to suffering. We need not surrender to evil, but we must accept it exists and engage in a ceaseless struggle with it.

In "Kol Dodi Dofek," the main way of contending with evil is through reflection - we turn inwards and see suffering and evil as a voyage of self-improvement, in which suffering redeems and refines. In the later essay, the contest with suffering unfolds by turning outwards to existence itself. Adopting topical Halakhah leads to a practical struggle with suffering and evil.

With great sensitivity, Soloveitchik recognizes that this approach to suffering "differs little from the attitude usually adopted by modern man toward evil. Modern man... is sensitive to the disorder and disharmony with which the universe is paced, and he is far from indulging in a happy-go-lucky contentment... Otherwise, he would not work so hard in order to find cures for some incurable diseases" (104).

Topical Halakhah, then, is compatible with the modern stance vis-à-vis the world, which refuses to surrender to the conditions of reality and constantly strives to amend it and reshape it. In this sense, thematic Halakhah is an obstacle to the amendment of 
reality. A theodicy that reconstructs harmony in theory makes the actual struggle against evil redundant.

Soloveitchik's outlook on this count resembles that of Camus, who also refuses to accept an other-worldly interpretation of the question of evil. Rieux, the doctor in The Plague, rejects Tarrou's attempts to explain evil. For Camus, the assumption about a metaphysical-transcendent order hinders the struggle against evil and leads to passivity. Rieux, who speaks for Camus, states: "Mightn't it be better for God if we refuse to believe in Him, and struggle with all our might against death, without raising our eyes towards the heaven where He sits in silence?"37

According to Camus, the struggle against suffering should be a driving force for humanity. Rieux claims that metaphysics should be rejected in favor of compassion and openness to suffering: "For the moment I know this; there are sick people and they need curing. Later on, perhaps, they'll think things over, and so shall I." ${ }^{38}$ Both Camus and Soloveitchik agree that we contend with evil through ethic. They disagree regarding the relationship between ethic and the religious stance. Camus holds that an ethic placing the suffering human being at its center must dispose of God and religion, which hinder practical action. Soloveitchik, by contrast, holds that this ethic can be a religious gesture of faith. Indeed, human beings should not turn to transcendence, but normative action per se is an affirmation that transcendence is present in this world.

In sum, Soloveitchik offers a complex model for coping with suffering and evil. He recognizes evil as a concrete given and, therefore, tends to reject theodicy as a way of contending with it. Whereas in "Kol Dodi Dofek" he rejects theodicy entirely, in "Approach to Suffering" he recognizes the presence of a theodicy trend in Jewish tradition. And yet, precisely in his attempt to deny the theodicy trend, Soloveitchik fails to displace 
the struggle against evil and suffering to the socio-political arena. The language of "Kol Dodi Dofek" points to personal fulfillment rather than to praxis, contrary to "Approach to Suffering," where Soloveitchik presents a practical blueprint for contending with suffering. Hence, whereas in "Kol Dodi Dofek" Hermann Cohen's influence translates into existentialist language, in "Approach to Suffering" he returns to Cohen's social approach.

Soloveitchik's approach to evil and suffering is that of a believer, so that the questions related to the religious meaning of this approach require further consideration. If the existence of evil should indeed be admitted, and if Jewish tradition, or at least its main stream, demands the adoption of a practical approach toward suffering and evil, what theology could substantiate this outlook? The fact that topical Halakhah is part of Jewish tradition raises the question: how to understand the fact that the giver of the Torah allows a reality of evil and suffering and establishes a Halakhah that acknowledges this reality? Soloveitchik's philosophy provides no answer to the contradiction between a reality of evil and God's goodness. Concern with this missing theological project is a unique feature of the philosophy of David Hartman, Soloveitchik's student. A hallmark of his philosophical endeavor is the removal of the theodicy trend beside the substantiation of a theology that enables this removal.

Hartman's main innovation is a renewed analysis of the religious-psychological role that theodicy had played in religious life. Hartman thereby reframes the theodicean discourse. A philosopher or a theologian dealing with the problem of theodicy is troubled by the contradiction between God's goodness and omnipotence versus the existence of evil in the world. In the context of religious life, however, the problem is entirely different: 
How do we respond to events that can call into question our whole identity as God's relational partners? Can we allow ourselves to embrace a personal God, knowing that chaos can at any moment invade our reality and arbitrarily nullify all our efforts and expectations? Do we have the strength to open ourselves to a personal God in a world filled with unpredictable suffering? When her child dies, the question a mother faces is less how to explain the logic of Torah's omnipotence than whether she has the strength and emotional energy to love again.

From the anthropological perspective on the problem of evil, therefore, the prime concern is not so much to defend the notions of divine justice and power. It is rather, as in other personal relationships, to determine what measure of continuity, stability, and predictability can enable the relationship with God to survive all shocks. ${ }^{39}$

Hartman's philosophy, therefore, replaces the question of theodicy, which is metaphysical, with the question of existentialism: how and whether believers can maintain their religious identity given the existence of evil and suffering. This shift follows from an understanding of the destructive role of evil and suffering in human life. Suffering erodes human confidence in existence: "One of the dimensions of suffering that often makes it unbearable is its arbitrariness. Suffering may involve not only physical pain, but also the disorienting terror resulting from the sufferer's belief that he is the victim of blind and irrational forces." 40

In Crisis and Leadership, Hartman holds that a person can contend with suffering "if he is convinced of some underlying purpose that gives meaning and order to his world." ${ }^{41}$ The metaphysical explanation of theodicy could meet this need by placing “a person's immediate experience within a broader framework, such as a grand plan or dramatic story spanning all of history." 42 
In this text, Harman lays the foundation for what will become a dominant element of his philosophy - the test of theodicy is not theoretical but practical. Theodicy cannot provide an absolute speculative solution to the problem of evil in the world; its ability to provide an answer is contingent upon the particular disposition of those who need it. Theodicy, then, has a socio-political rather than a metaphysical role. Hartman illustrates this approach with an analysis of various solutions that Maimonides proposes for suffering and pain. In his view, Maimonides was aware of the socio-political role of theodicy. Therefore: "In addressing the sufferer, one must be sensitive to the specific needs of the person in question. Because Maimonides [in the "Epistle to Yemen"] is trying to comfort and encourage a suffering community, he uses multiple models and suggestions directed at the different types of people comprising his audience." ${ }^{43}$ This functional perception of theodicy enables Hartman to make two moves. The first is to explain the existence of a tradition endorsing theodicy in Judaism, and the second is to dismiss the metaphysical value of this approach and reexamine it. His conclusion is that theodicy is a cognitive answer to the problem of evil, whose sole test is the measure of its acceptance:

A constant gap between our perception of our relationship to a personal God and the reality of the world that we believe He created and rules is liable to give rise to repeated frustration. The question then is: How long can any attempt to cope with the frustration succeed in containing it? How long is it before we decide that the relationship no longer exists or that it is not worth having? To this question there is no single universal answer applicable equally to all human beings. ${ }^{44}$

Hartman can now argue that the various rabbinic responses to suffering, relating to it as "chastenings of love" or calls to 
repentance, ${ }^{45}$ can hardly be considered decisive answers to this question. In principle, we can hardly predict what response will comfort a suffering soul, and this is a matter contingent on the difference between human dispositions:

Some find the unpredictable dimensions of reality to be [so] overwhelming...For them, suffering is bearable if it results from the limitations of finite human beings, but it becomes terrifying and demonic if it is seen as part of the scheme of their all-powerful Creator. Others would find life unbearably chaotic if they could not believe that suffering, tragedy, and death were part of God's plan for the world feeling that there is meaning and order in the world and that God in His wisdom decided to terminate the life of their loved ones makes their tragedy bearable. (202)

This approach continues the programmatic line that Soloveitchik had set originally, but is expressed more coherently in Hartman's thought. From a pragmatic-empirical vantage point, the traditional theological discussion of the problem of evil is merely a "disruption," since human beings do not opt for faith (or the alternative) as a function of theological or theodicean propositions (201-202). We can handle evil only by shifting the center of gravity to a life of actual faith (202). Hartman speaks of this displacement as a transition from "philosophical theology" to "religious anthropology" (187). The crucial question is not the one bearing on theology and theodicy but the religious-existentialist question. In this discussion, the key issue is the person's ability to go on believing when faced with evil, not the justification of God. In Hartman's terms, the main question is not theodicy, but the modes of response to suffering (16).

Existentialist faith assumes that, structurally, the relationship with God resembles human interactions $(187,202)$. Human 
relationships are constantly tested and contingent on real events, as well as on the baggage borne by each individual. Individuals have expectations from God, and relate to God as loving and just. The rift of evil casts doubts on the possibility of sustaining this view. People do not ask themselves whether God is right, but "how can I sustain commitment to a way of life predicated on God's covenantal love and justice?" (188). This question is doomed to remain open, since no universal, metaphysical single solution can provide answers to human distress.

For Hartman, the practical-existential shift of the problem of evil and suffering is anchored in two mutually related considerations: one is human responsibility and freedom, and the other is covenantal theology. The theodicean view of suffering could hinder human readiness to act - if suffering, evil and pain are justified, why struggle against them?: "If we are to uphold the dignity implied by the notion of the covenant, with its full respect for ourselves as rational and moral beings, we must reject attempts to see all of nature and history as mediating God's personal will" (276). This consideration is based both on the primary affirmation of human rationality and of our value as human creatures, and on the appropriate theology. The primary affirmation of human value is embodied in the refusal to adopt a disposition of constant guilt. This disposition is imperative for the endorsement of a theodicean view - if the God that is the cause of suffering and evil is right, human beings are guilty. Relentless guilt is a deep injury to a sense of worth, to the possibility of experiencing ourselves as free agents allowed to operate according to our own understanding (276). This theodicy, then, "in no way fits what we know about ourselves in reality" (276). In sum, a theodicy that justifies God humiliates human beings, affronts their dignity, their understanding of reality, and their freedom. 
In Hartman's thought, this incongruence between human worthiness and a theodicean viewpoint conveys a deep incompatibility between theodicy and covenantal theology. Hartman's philosophical endeavor is an attempt to reframe covenantal theology, which allows to present evil and suffering in religious-existentialist terms rather than in a theodicean context.

Covenantal theology is based on the assumption that God and human beings act as partners entering a covenant - on the one hand, God as a personality, and on the other, the Jewish collective. Hartman clarifies in his analysis the meaning of this interpersonal partnership. The God of the covenant is not the "Aristotelian God" but a personality, meaning that causality categories are irrelevant: as a personality is multifaceted and unresponsive to this category, so is God (200).

Similarly, the human partner also deserves dignity and respect: "the covenant encourages human dignity and initiative" (187). The covenant, wherein God enters into a partnership with human beings as creatures who are at once limited and free, is an affirmation of human existence in its finitude. ${ }^{46}$

Covenantal theology is based on a limitation of God's role in the natural and historical world on the one hand, and on the imposition of responsibility on human beings on the other. The displacement of the burden of responsibility is evident, above all, in God's removal from nature and history:

We do not have to seek a personal manifestation of God in the events of nature or of history. Suffering and human tragedy are not signs of divine rejection or punishment. God's providential concern is manifested in the guidance provided by the Torah. God is present as a personal reality through the hearing of mitzvot. (17) 
The meaning of this displacement implies a recognition of history's and nature's neutral character. Human beings are sovereign agents in history, and historical events are within the realm of human responsibility. The world has the regularity of nature, in which God never interferes. For Hartman, this approach is fully evident in Maimonides' philosophy, which he analyzes at length (232-236). The neutralization of history and of nature is a full affirmation of reality: the only reality is immanent reality. It is neither justified by invoking a theodicy nor is it a stage in an eschatological outlook:

It does not aim to redeem the creature from creaturely finitude, nor does it point to an existence not shot through by the problematics of human freedom and temporality...the God of Sinai does not promise that history will be secure against the misuse of human freedom. Failure, uncertainty, and unpredictability are permanent features of life under the covenant, since human freedom is constitutive of the covenantal relationship. (261)

This theological framework clarifies the depth of the chasm between Soloveitchik and Hartman. In "Kol Dodi Dofek," as noted, Soloveitchik yearns for a theodicy. This yearning does indeed disappear in his later essay, "Approach to Suffering," but there too he acknowledges the possibility of a theodicean context as a plausible approach for contending with evil. Like Leibowitz and Goldman, Hartman too utterly rejects the theodicean option, and criticizes Soloveitchik because he longs for "the eschatological moment of unity between nature and history, when the God of Creation will be manifestly mediated in His full loving justice in historical reality" (267-268). This criticism does not apply to Soloveitchik's later essay, which was not available to Hartman 
when writing his critique. But Soloveitchik posits the option of thematic Halakhah, which is rejected in Hartman's covenantal theology. In sum, in Hartman's philosophy, human evil and pain are a constant challenge to human responsibility. As members of the covenantal community, human beings should not expect theodicean explanations or eschatological redemption. They should instead struggle against evil, as a way of realizing their freedom.

The common denominator of all the thinkers discussed in this chapter is the rejection of theodicy as a metaphysical problem and its transformation into a practical question concerned with life itself. Goldman and Leibowitz hold that theodicy is the testing point for the disposition of the faithful and the way they organize their world. By contrast, Soloveitchik and Hartman hold that the theodicy problem is a replacement of the genuine problem: human responsibility for the condition of the world. 
1 For an analysis of this solution and its limitations, see Avi Sagi and Daniel Statman, Religion and Morality, trans. Batya Stein (Amsterdam and Atlanta, GA: Rodopi, 1995), 136-138.

2 Eliezer Goldman, Expositions and Inquiries: Jewish Thought in Past and Present, ed. Avi Sagi and Daniel Statman (in Hebrew) (Jerusalem: Magnes Press, 1996), 361.

3 Ibid.

4 Yeshayahu Leibowitz, Judaism, the Jewish People, and the State of Israel (in Hebrew) (Tel Aviv: Schocken, 1976) (henceforth Yahadut), 358-359.

5 Goldman, Expositions and Inquiries, 362.

6 See Avi Sagi, Tradition vs. Traditionalism: Contemporary Perspectives in Jewish Thought, trans. Batya Stein (Amsterdam-New York: Rodopi, 2008), 43-60.

7 See Eliezer Goldman, "Divine Good and Human Good" (in Hebrew), News of the Religious Kibbutz 107 (March 1955). Because of the fragmented, local context of the article, we did not include it in the main anthology of Goldman's writings, and I now correct that mistake.

8 Richard Hare, who may have influenced Goldman, made this claim about moral discourse itself: in moral language, the term good 
denotes what is worthy and the term bad what is unworthy, but this language use need not lead us to conclude the existence of one sole moral criterion. See Richard M. Hare, The Language of Morals (Oxford: Oxford University Press, 1952), particularly ch. 6.

9 The Collected Dialogues of Plato, ed. Edith Hamilton and Huntington Cairns (New York: Bollingen Foundation, 1961), 1108. For a discussion about this perception of the good and its development, see Arthur O. Lovejoy, The Great Chain of Being: A Study in the History of an Idea (Cambridge, MA: Harvard University Press, 1970), 39-45.

10 Goldman, "Divine Good and Human Good," 16.

11 Goldman, Expositions and Inquiries, 343-345.

12 Avi Sagi, "Religious Language in the Modern World: An Interview with Eliezer Goldman" (in Hebrew), Gilayion (August 1995), 13.

13 For further discussion, see Sagi, Tradition vs. Traditionalism, 122125.

14 Goldman, "Divine Good and Human Good," 17.

15 Yahadut, 391-394; Yeshayahu Leibowitz, Five Books of Faith (in Hebrew) (Jerusalem: Keter, 1995), 36.

16 Ibid., 29-30.

17 Judaism, 50.

18 Leibowitz, Five Books of Faith, 31-32.

19 Ibid., 32.

20 Judaism, 52.

21 Leibowitz, Five Books of Faith, 39.

22 Rudolf Bultmann, "Is Exegesis without Presuppositions Possible?" in The Hermeneutics Reader, ed. Kurt Muller-Vollmer (New York: Continuum, 1989), 242-247.

23 Yahadut, 393. See also Yeshayahu Leibowitz, Seven Years of Talks on the Weekly Torah Reading (in Hebrew) (Jerusalem: n. p., 2000), 85; idem, Notes on the Weekly Torah Reading (in Hebrew) (Jerusalem: Academon, 1988), 21; idem, Talks on Maimonides' Eight Chapters (in Hebrew) (Jerusalem: Keter, 1986), 197; idem, Five Books of Faith, 22-23.

24 Joseph Dov Soloveitchik, "Kol Dodi Dofek: It Is the Voice of My Beloved that Knocketh" (henceforth "Kol Dodi Dofek"), in Theological and Halakhic Reflections on the Holocaust, ed. Bernhard Rosenberg (New York: Ktav, 1992), 57-117. 
Joseph B. Soloveitchik, "A Halakhic Approach to Suffering," (henceforth "Approach to Suffering") in Out of the Whirlwind: Essays on Mourning, Suffering, and the Human Condition, ed. David Shatz, Joel B. Wolowelsky and Reuven Ziegler (New York: Ktav, 2003), 86-115.

"Kol Dodi Dofek," 52.

27 For further discussion of the subjective shift, see Sagi, Tradition and Traditionalism, 21-24.

28 Hermann Cohen, Religion of Reason Out of the Sources of Judaism, trans. Simon Kaplan (New York: Frederick Ungar, 1972), 135.

29 See Aviezer Ravitzky, "Rabbi J. B. Soloveitchik on Human Knowledge: Between Maimonides and neo-Kantian Philosophy." Modern Judaism 6 (1986), 157-188.

30 “Kol Dodi Dofek," 54.

31 Ibid., 56. This analysis is opposed to Sokol's interpretation of Soloveitchik's approach. In his view, Soloveitchik endorses Hermann Cohen rather than the existentialist view. See Moshe Sokol, "Is There a 'Halakhic' Response to the Problem of Evil?," Harvard Theological Review, 92 (1999), 316-320. Sokol's emphasis on Cohen's legacy is definitely accurate, but he is not persuasive in his attempt to dismiss existentialist foundations from Soloveitchik's thought.

32 "Kol Dodi Dofek," 54.

33 David Hartman, A Living Covenant: The Innovative Spirit in Traditional Judaism (New York: Free Press, 1985), 267-268.

34 "Kol Dodi Dofek," 56.

35 Ibid., 62 (emphasis in the original).

36 "Approach to Suffering," 94.

37 Albert Camus, The Plague, trans. Stuart Gilbert (Harmondsworth, England: Penguin Books, 1961), 108.

38 Ibid., 107.

39 Hartman, A Living Covenant, 187.

40 David Hartman, Crisis and Leadership: Epistles of Maimonides (Philadelphia: Jewish Publication Society of America, 1985), 162. See also A Living Covenant, 247.

41 Hartman, Crisis and Leadership, 163. 


\section{Chapter Five}

42 Ibid.

43 Ibid., 164. See also 171.

44 Hartman, A Living Covenant, 200.

45 Hartman analyzes these and other responses in A Living Covenant, ch. 8 .

46 See ibid., ch. 11. 